Meta

Journal des traducteurs

Translators' Journal

\title{
Terminology in Japan
}

A Descriptive Overview of its Development

\section{Masanobu Fujikawa}

Volume 33, numéro 1, mars 1988

Traduction et interprétation au Japon

Translation and Interpretation in Japan

URI : https://id.erudit.org/iderudit/003592ar

DOI : https://doi.org/10.7202/003592ar

Aller au sommaire du numéro

Éditeur(s)

Les Presses de l'Université de Montréal

ISSN

0026-0452 (imprimé)

1492-1421 (numérique)

Découvrir la revue

Citer cet article

Fujikawa, M. (1988). Terminology in Japan: A Descriptive Overview of its

Development. Meta, 33(1), 94-103. https://doi.org/10.7202/003592ar d'utilisation que vous pouvez consulter en ligne.

https://apropos.erudit.org/fr/usagers/politique-dutilisation/ 


\title{
TERMINOLOGY IN JAPAN : A DESCRIPTIVE OVERVIEW OF ITS DEVELOPMENT*
}

\author{
MASANOBU FUJIKAWA \\ University of Library and Information Sciences \\ (ULIS), Tsukuba, Japan
}

\section{THE PRESENT STATE OF TERMINOLOGY STUDIES IN JAPAN}

Higher animals have their own languages, as much observation, experimentation and research have proved, but none of them seems to have the capacity to express abstract ideas, which is a particularity of human language. To clarify this capacity peculiar to human language, one must study man's information processing mechanism and find man's intellectual faculties. Research on this matter is one of the central issues of artificial intelligence and is directly related to the fundamental aspect of terminological studies. New terminological studies based on cognition are now being carried out in Japan.

However, there are many problems to be solved with respect to the structure of Japanese vocabularies. The late Iwabuchi, a famous linguist, discussed the problem of technical terms, in contrast to common words, in the following terms :

Audible words are to be comprehended through the sense of hearing. But there are many technical terms which can hardly be understood when they are pronounced. Generally speaking, many technical terms, especially the terms used in academic fields, were created in written form. Therefore, unless they are expressed in Chinese characters, even the specialists may not be able to grasp the correct meanings... ${ }^{1}$ (abstracted and translated by Fujikawa)

Hisakazu Kaneko, a professor of the Japanese language, states the problem caused by the notation of words in Chinese characters. He says,

The barrier of the Japanese language is formed by the extraordinary complexity of the use of Chinese characters, not by its grammar,

and continues,

there are nine main problems in the use of Chinese characters in the Japanese language.

1. Pronunciation of most of the Chinese characters used in the Japanese language is to be solely drawn from one's memory when no explanation of circumstantial conditions is indicated.

2. When a word is notated by two Chinese characters, in many cases one character is read in Chinese pronunciation and the other in Japanese pronunciation.

3. One Chinese character, or a word composed of two or more Chinese characters, has manifold meanings.

4. There are quite a few meaningful units, each of which is expressed by two or more Chinese characters, the meanings of which have or are considered to have some relation with the meaning of each of Chinese characters used but have no relation with the forms of the units (words) structured by the Chinese characters. 

quantity.

5. Words structured by two or more Chinese characters of similar meanings exist in

6. Many Chinese characters have several so-called "Chinese pronunciations" but one Japanese pronunciation in Japanese.

7. A combination of Chinese characters often corresponds to different kana spellings.

8. Each Chinese character as a constituent of a word is often pronounced differently from the original pronunciation of the character.

9. Quite often, the Chinese characters are used as phonetic symbols to notate words. ${ }^{2}$ (Abstracted and translated by Fujikawa.)

It is clear from the above that with the ever increasing processing of scientific information terminological studies are required to solve problems associated with the notation of words expressing concepts and ideas. Work is also required on the ways and means of organizing vocabularies and of selecting vocabulary entries.

Many articles and special issues of periodicals have been devoted to language studies in recent years, and among them there are some interesting articles which discuss the characteristics of registering voices of the Japanese people based upon Tsunoda's theory of functional differences between the right and left cerebral hemispheres.

With respect to the basic vocabulary of special subject fields, Takano and Toriumi have introduced the idea of the Japan Information Center of Science and Technology (JICST).

First they provide definitions for two basic concepts :

1. Terms used in special subject fields : the terms which are frequently used, in comparison with other terms, in the literature of science and technology : in other words, the terms needed to convey information on science and technology.

1. Basic terms,

(1) The terms which have great influence on the appropriate distribution of scientific and technological information as a whole.

(2) The terms which have no substitutes,i.e. synonyms and compounds of different words.

Based on the above definitions, they identify basic vocabulary as the group of terms that belong to the following categories :

1. Terms of statistically frequent use ;

2. Terms that are neither synonyms nor compounds.

The authors have also introduced the following items :

1. Jicst file on scientific and technological literature

2. Key words

3. Thesaurus

4. Terms in the JICST Thesaurus

5. Expansion and organization of basic terms

6. Basic terms from the statistical point of view, providing the representative data acquired through various experiments and the compilation work of the Thesaurus $^{3}$. (Abstracted and translated by Fujikawa)

Kagaku Gijutsu Joho Katsudo Suishin Kondankai (Group to Promote Science and Technology Information Activities) published, in 1978, a report named Kagaku Gijutsu Joho Katsudo Suishin no Mokuhyo to Seisaku ni tsuite (On the Objective and Policy to Promote Science and Technology Information Activities). The aim of this report is to make clear the concept and scope of the National Information System for Science and 
Technology (NIST) and to describe concrete means to realize the concept. It refers to the problem of terminology in several places and emphasizes the importance of the examination of terms used for retrieving information on the grounds of the particular characteristics of the Japanese language and the need for preparing standardized scientific terms.

In the report published by Mitsubishi Sogo Kenkyusho (Mitsubishi Research Institute) ${ }^{4}$, the present state and the future of information retrieval by natural language is discussed in terms of database structure and function, and the trend of machine translation is explained by citing several sample cases. In these two sections, the issue of terminology is taken up indirectly.

It may be concluded that terminological studies in Japan today have as their objective 1) the study of the lexicon in specialized fields, 2) the development of ways and means of collecting, selecting, and identifying the terms required to convey information.

\section{CHARACTERISTICS OF SCIENTIFIC-TECHNICAL TERMINOLOGIES IN JAPAN REFLECTING THE STRUCTURAL FEATURES OF JAPANESE LANGUAGE}

Norinaga Motoori, a famous Japanese classical scholar and philologist in the middle of the Edo period (1730-1801), stated in his work entitled Uiyamabumi : "It can be generalized that words, things and matters, and mind are integrated and equilibrated in most people..." (tr. by Fujykawa). This may be a very naive linguistic opinion, but what he said can rightly be considered as the basis of terminological studies being pursued in many disciplines today.

Hidetoshi Kato, a well known sociologist, says,

As for the modern history of Japan, many people may think that words have become easier to comprehend with the gradual decrease of words expressed in Chinese characters. But there is a surprising fact. It is that Japanese people are beginning to use more Chinese characters in contrast with the generally accepted impression...

and cites the following table prepared by Yoshibumi Tobita 5 .

\begin{tabular}{lccccc}
\hline & $\begin{array}{l}\text { Traditional } \\
\text { Japanese } \\
\text { words }\end{array}$ & $\begin{array}{l}\text { Words expressed } \\
\text { by Chinese } \\
\text { characters }\end{array}$ & $\begin{array}{l}\text { Foreign } \\
\text { words }\end{array}$ & $\begin{array}{l}\text { Mixed } \\
\text { words }\end{array}$ & Total \\
\hline $\begin{array}{l}\text { Meiji } \\
\text { period }\end{array}$ & 79 & 20 & 0 & 1 & $100 \%$ \\
\hline Taisho period & 53 & 39 & 0 & 8 & $100 \%$ \\
\hline $\begin{array}{l}\text { Showa } \\
\text { period }\end{array}$ & 43 & 54 & 1 & 2 & $100 \%$ \\
\hline
\end{tabular}

Note : Meiji period (1868-1912), Taisho period (1912-1926), Showa period (1926 to date).

As is widely known, a big obstacle to solving the problem of Japanese terminology lies in the fact that, not only in daily life but in all research fields, three different types of characters i.e. Chinese, hira-gana, and kata-kana, are used to express concepts and 
ideas. Moreover, Roman characters are employed in many cases. This means that, in Japan, the use of characters must be controlled before terminology is regulated.

The above-mentioned problem is directly related to the issue of language information processing, and it is made more difficult by the lack of orthography in the Japanese language. This lack is due to the use of Chinese characters, but it is also due to the form of expression (notational system) which has no regulation of word division in the mixed use of Chinese characters and kanas. The lack of orthography is considered a fatal defect in the language of any modern nation and has given rise to many discussions among linguists and information scientists in relation to the development of Japanese word processors.

Besides the above problem, the structural features of the Japanese language have attracted attention. MacDougall, a professor at the University of Camberra, contributed an article to a Japanese periodical and expressed the following opinion :

There are three main difficult points in learning the Japanese language. The first are characters as related to the problem of orthography.

The second is the issue of pronunciation or phonetics : in the Japanese language, the number of vocal sounds is relatively small, much less than that of English language, but subtle differences in the pronunciation of Japanese vowels derived from English vowels cause troubles for English speaking people. There is another phonetic problem. To the English speaking people, many Japanese

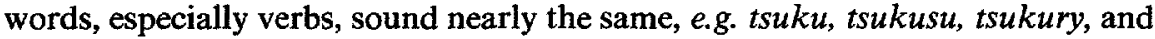
tsukau. Of all the Japanese words, over one third begin with either $k$ or $s$, e.g. in 1454 pages of Kenkyusha's Simplified Japanese-English Dictionary, 269 pages are devoted to the words the first letter of which is $k$, and 274 to words starting with the letter $s$. In the same dictionary, there are 16 different words pronounced "köshö".

The third deals with grammar and sentence structure :

1. Although people criticize the ambiguity of Japanese sentence structures, this ambiguity is not caused by the structural characteristics of Japanese sentences. The Japanese language allows a speaker or a writer to express his idea in an ambiguous or indirect way and to emphasize feelings rather than facts. It will be necessary to understand this problem from the cultural aspect rather than the linguistic aspect.

2. The use of particles is sometimes incomprehensible to English speaking people. However it is unreasonable to expect clear-cut correspondence between Iapanese particles and English prepositions, conjunctions, and some other adverbial expressions.

3.Erroneous usage by mistaken analogy. This is caused by the mistaken analogy of wording patterns, mainly by the adjectival verb peculiar to Japanese grammar.

4. Problems in forming verbs. To the general English speaking people, it is a great trouble to build up a form of a verb by piling up morphemes.

5. Problems of honorifics.

6. Problems of word order. The order of words in the Japanese language is remarkably different from that in the English language, and this poses the most difficult problem to foreigners whose vernacular language has a word order similar to that in English. This is especially true when a sentence excedes a certain length. ${ }^{6}$ (Abstracted and translated by Fujikawa) 
The rather long citation above seems to have correctly and explicitly described the characteristics of the Japanese language.

\section{HISTORICAL ASPECT OF JAPANESE TERMINOLOGIES}

To describe the historical aspect of Japanese terminologies it may be appropriate to begin with an overview of the scientific studies undertaken before the Meiji Restoration (1868) because the advancement of scientific research after the Restoration was based on studies in the Edo period, which precedes the Meiji period.

It was in 1543 that Japan first made contact with Western civilization through the import of firearms from the Netherlands. In 1549, Francisco Xavier, a Spanish missionary, came to Kagoshima (the southern-most part of mainland Japan) and many missionaries came to Japan after him. Besides their involvement in missionary tasks, they provided medical services and disseminated popularized knowledge of astronomy and geography. They also introduced the products of their civilization, such as clocks, glasses, and printing machines.

However, after the Tokugawa Shogunate started to dominate the whole country, it adopted a policy of isolation and, in 1630, prohibited the importation of Western books and their Chinese translations. Mathematics and astronomy, however, developed in the following period and had great influence upon scientific studies.

In 1720 Yoshimune Tokugawa removed the ban on the importation of Western literature except religious books, and after that books written in Dutch began to be imported. The translation of "Tafel Anatomia", which was published in 1775, made a great contribution to modern Japanese medicine, and this was followed by the serious study of the Dutch language, as shown by Gentaku Otsuki's Rangaku Kaitei (Introduction to Dutch Studies) published in 1788 and Sanpaku Inamura's Halma Wage (DutchJapanese Dictionary based on Halma's dictionary) in 1796.

Following medical studies, botany and natural history were introduced to Japan through translations, and by the last stage of the Tokugawa period, the main subject fields of the natural sciences were organized according to the scientific method in the Western world.

However, starting with the end of the 18th century, it became necessary to study English, French, German and Russian to have access to Western science and to cope with the rapid change in foreign relations.

From the beginning of the Meiji period (1868-1912) Japan started to establish academic societies, colleges and research laboratories and to invite professors, researchers, and physicists from the Western world. Along with this rise in scientific studies, taxonomies, classification schemes, glossaries and dictionaries were compiled in various subject fields.

The following are some examples of terminological studies in the Meiji period.

1871 : Yoshio Tanaka prepared Shida Bunrui Meiji (Classified Terms of Ferns).

1880 : Massayuki Nakagawa proposed the standardization of mathematical terms.

1884 : Tozo Matsumura compiled Nihon Shokubutsu Meiji (Glossary of Japanese Botanical Names).

1888 : Tokyo Sugaku Butsuri Gakkai (Tokyo Academic Society of Physics and Mathematics) published Butsurigaku Jutsugo Jisho (Multilingual Dictionary of the Technical Terms of Physics. Japanese-English-German-French) the first dictionary of technical terms in Japan (revised in 1905).

1889 : Rikitaro Fujisawa prepared Sugaku Yogo Ei-Wa Taiyaku Jisho (English-Japanese Dictionary of Mathematical Terms). 
1891 : Tokyo Kagakukai (Tokyo Chemical Society) published Kagaku Yakugoshu (Glossary of Translated Chemical Terms).

1900 : Joji Sakurai, Toyokichi Takamatsu, and Koichi Matsubara edited Kagaku Goi (Glossary of Chemical Terms).

1902 : Kintaro Okamura compiled Nihon Sorui Meii (Glossary of Japanese Algae Names).

1912 : Tozo Matsumura edited Teikoku Shokubutsu Meikan (Directory of Japanese Botanical Names).

In the Taisho period (1912-1926) there were no prominent terminological studies, but the following may be listed as examples of the work done.

1912 : Kokugo Chosa Iinkai (Committee for Japanese Language Research) published Gimon Kanazukai (The Problematic Use of Kana) in 2 vol.

1914 : Naohide Yatsu compiled Dobutsu Bunrui Hyo (Taxonomic Table of Animals).

1916 : Kokugo Chosa Iinkai (ditto) published Kogo Ho (Writing Rules in Colloquial Style).

1921 : Rinji Kokugo Chosa Kai (Provisional Council for Japanese Language Research) was established and started to work on the investigation of Japanese letters and language.

1923 : Monbu-sho Rinji Kokugo Chosa Kai (Provisional Council for Japanese Language Research, Ministry of Education) proposed 1963 Chinese characters for daily use and 154 simplified Chinese characters.

In the Showa period (1926 to date) Japan went through a great upheaval, and scientific studies were strongly promoted but, on the other hand, the freedom of learning was heavily restricted before and during World War II. The results of terminological studies are as follows.

1926 : Shinko-sha (Shinko Publishing Co.) published Banyu Kagaku Taikei (Encyclopaedia of Science and Technology), a well-systematized Encyclopaedia in 18 volumes covering important terms.

1926 : Onsei Gakkai (Academic Society of Phonetics) was established.

1930 : Takuro Tamaru published Romaji Kokuji Ron (An Essay on promotion the Adoption of Roman Letters as Japanese Letters).

1930 : Rinji Romaji Chosa Kai (Provisional Council for the Research of Roman Letters) was established.

1933 : Meiji Shoin (Meiji Publishing Co.) published Kokugo Kagaku Koza (Series of Japanese Linguistic Studies).

1934 : Kokugo Shingi Kai (Japanese Language Research Council) was established in Monbu-sho (Ministry of Education).

1937 : The Cabinet issued an order to standardize the romanizing of the Japanese Language.

1938 : Nihon Gengo Gakkai (Japan Academic Society of Linguistics) was established.

1942 : Kokugo Shingi Kai (ditto) submitted Hyojun Kanji Hyo (Table of Standard Chinese Characters), in which the total number of the characters was 2669 and the number of simplified characters was 80 .

1944 : Kokugo Gakkai (Academy of Japanese Language) was established. 
1946 : Nihon Romaji Gakkai (Society for the Promotion of the Use of Roman Letters) and Kanamoji Gakkai (Society for the Promotion of the Use of Kana) promoted the adoption of Japanese style Romanization, the diffusion of laterally written Kata-kana, and the abolition of the use of Chinese characters.

1946 : The Governement proposed a table of 1850 Chinese characters designated for daily use and the current rule of the use of kana.

1947 : Under the Special Committee for the Research of Scientific Literature of the gakujutsu Kenkyu Kaigi Council for the Scientific Research, a subcommittee to establish academic and technical terms was organized.

1948 : Kokuritsu Kokugo Kenkyusho (National Language Research Institute) was established.

1953 : Kokugo Shingi Kai (ditto) proposed a plan for the unification of Romanized spelling, based on Kunrei-shiki (Government Instruction Method) in principle.

1954 : The Government provided instruction in the Romanized spelling. In principle the Kunrei-shiki method was used, although the Hepburn Method and the Nippon Method were employed in some cases.

1959 : The Cabinet Council standardized Okurigana (adding of kanas at the end of Chinese characters to identify their pronunciation).

1959 : Kokugo Mondai Kyogi Kai (Conference for Language Problems) declared its opposition to the above standardization.

1960 : Nihon Bungei-ka Kyokai (Japan Association of Literary Artists) publicized its opposition to the one-sided reform of the Japanese language by the Ministry of Education.

1964 : Kokugo Mondai Kyogi Kai (ditto) presented a petition to the Government to abolish the Okurigana (ditto) method and Toyo Kanji On-kun Hyo (Table of Pronunciations for both Chinese sounds and Japanese sounds of Chinese characters in daily use).

As these items indicate, the biggest issue in Japanese terminological studies and Japanese terminologies is the standardizing and unifying of methods for noting words using Chinese characters, kanas, Roman characters, etc.

At the same time, it has to be admitted that the terminologies (glossaries, vocabularies) in each subject field were originally dependent upon the translation of Western language textbooks in each field, which resulted in a lack of consistency in structuring groups of terms from the standpoint of the terminological science. The reasons for this are the following : 1) in the translated works, concepts were interpreted in a given context expressed by a string of terms ; 2) each term was considered as a mere constituent of that context ; 3) the significance of extracting and unifying terms was not recognized.

Linguistic researchers and information scientists are now tackling both the linguistic problems peculiar to the Japanese language and the terminological problems, through about a dozen authorized organizations, listed in, the World Guide to Terminological Activities ${ }^{7}$.

Note : The data found in this Section is extracted mainly from :

1. Suketoshi Yajima and Kentaro Nomura Ed. (1954) : Meiji Bunka-shi, Gakujutsu-hen (The Volume for Learning, Cultural History of Meiji Period), Yoyo Sha (Yoyo Publishing Co.), 843 p.

2. Takeo Okano (1954-1955) : Shuppan Bunka Shi (History of Publication Culture), Muromachi Shobo (Muromachi Publishing Co.), 2 vols.

3. Kindai Nippon Sogo Nenpyo (Chronological Table of Modern Japan) 1853-1967, Iwanami Shoten (Iwanami Publishing Co.), 1968, 461+71 p. 


\section{TERMINOLOGICAL STUDIES IN ACADEMIC FIELDS}

1. In the Ordinance of Nihon Gakujutsu Kaigi (Science Council of Japan), established in 1967 and amended in 1976, it is stated that one of the tasks of the Council is the establishment and diffusion of scientific terms and that a Sectional Committee shall be set up to realize the task.

The Committee is expected to carry out the following objectives.

1. Collecting and recording terms : to collect scientific terms, paying attention to synonyms, near-synonyms, and antonyms, to identify their sources, and to record them.

2. Selecting terms : to examine, reject, and select the collected terms, or to improve them, and to prepare a draft of research on "terminology" through a comprehensive standardization of scientific terms.

3. Adjusting terms : when there are more than two established or selected scientific terms expressing the same concept, to prepare a plan for the coherent use of those terms in neighboring or related subject fields.

4. Inspecting terms : to reexamine systematically the draft plan of the scientific terms that have been selected and adjusted in accordance with Kakujutsu Yogo Shinsa Kijun (Criteria for the Inspection of Scientific Terms).

2. In the above criteria, prepared in 1969 and amended in 1973, the following points are stated.

1. Definition of scientific terms. A scientific term is a term to express a scientific concept.

2. Principles of Criteria for Inspection

(i) A scientific concept has to be properly expressed.

(ii) A scientific term has to be properly formed as a term.

(iii) A scientific term has to be simple and plain.

(iv) A scientific term has to be unified in use in each subject field.

(v) The use of Chinese characters and kanas and the addition of kanas to the preceding word stems are to follow either the Notice by the Cabinet or other proper criteria.

3. The policy on the use of symbols of various kinds was made clear as early as 1953. The representative symbols are parentheses and brackets.

4. "General Rules for Naming Japanese Terms derived from English Words : 'degree', 'ratio', 'coefficient' and 'specific'..." (the original in English) were announced in 1972.

5. "How to Romanize Japanese Scientific Terms" was published in 1974.

Under the Ordinance and the above-mentioned regulations, the publication of a series of Gakujutsu Yogo-shu (Glossary of Scientific Terms) was planned ; as of March 1981, 34 glossaries were listed, and April 1986, 26 subject fields were covered and more glossaries were in preparation.

However, these glossaries have a common defect, that is all of them are mere lists of Japanese scientific terms with one-to-one English correspondents. They do not provide any definition and references. Therefore, it is impossible to utilize any of them as a dictionary or a thesaurus.

Yasuo Kagawa, a professor of biochemistry, says that scientific terms have to be located on the contact point of information machines and their users, and draws attention to the following points.

1. Interdisciplinary nature of scientific terms. The advancement of research in subject fields having an interdisciplinary nature has made it necessary to exchange wide-ranging information as represented by biotechnology and clinical technology. It is 
therefore necessary to unify the terms which have been customarily used by specialists in each of the narrow subject fields. But there is no glossary covering interdisciplinary areas among the Gakujutsu Yogo-shu published by Monbu-sho (The Ministry of Education and Culture). Unification of scientific terms is a necessity.

2. The lack of verbs and adjectives in presently available glossaries of Monbu-sho and dictionaries of scientific terms causes problems in machine translation. The lack of terms to express experimental operations and thinking processes hinders understanding and comprehension.

3. The provision of means to input Japanese terms in Romanized form is required.

4. Databases of scientific terms e.g floppy disk version to be used for word processors, are in great demand.

5. Reexamination of the role of Chinese characters may be necessary as they have strong points in view of pattern recognition.

In conclusion he stresses that those who establish scientific terms should be researchers and educators themselves ${ }^{8}$.

\section{CONCLUSION}

Though there are a great many dictionaries and glossaries in Japan, it is strongly felt that the fundamental and theoretical effort has to be carried out by the cooperative efforts of scientists, linguists, information technologists, and lexicographers.

Cited references

1. IWABUCHI, Etsutaro (1977) : Nihongo o Kangaeru (To Think About the Japanese Language), Kodansha, pp. $178-179$.

2. KANEKO, Hisakazu (1985.3) : "Tango no hyoki to kanji" (Notation of Words and the Chinese Characters), Kokubungaku : Kaishaku to Hihyo (Japanese Literature : Interpretation and Appreciation), vol. $50, \mathrm{n}^{\circ} 3$, pp. 64-87.

3. TAKANO, Fumio and Tsuyoshi TORIUMI : "Senmon bunya no kihon goi" (The Basic Vocabulary of Specialized Subject Fields), Nihongo Gaku (Japanese Language Studies), vol. 20, no 2, pp. 57-69.

4. Mitsubishi Sogo Kenkyusho (Mitsubishi Research Institute) Kagaku Gijutsu Joho no Kokusaiteki Ryutsu no Arikata ni kansuru Chosa Kenkyu Hokokusho (Research Report on the International Distribution of Science and Technology Information), 1985, 330 p.

5. KATO, Hidetoshi : Jiko Hyogen (Self-Expression), Chuko Shinsho (Pocketbook Series of Chuo Koron Pub. Co.), no 521, p. 15.

6. McDOUGALL, Ian A. (1985.3) : "Nihongo no kokoga mutsukashii" (This is the Difficult Point of the Japanese Language), Kokubungaku : Kaishaku to Hihyo (ditto), vol. 30, no 3, pp. 6-21.

7. "World Guide to Terminological Activities", 2nd rev. and enl. ed. (Infoterm Series 4), München, K.G. Sauer, $1985,158 \mathrm{p}$.

8. KAGAWA, Yasuo (1985.6) : "Johoka jidai to gakujutsu yogo" (Information Age and Technical Terms), Kagaku (Science), vol. 55, no 6, p. 329.

Other Japanese References Cited in the Full Version of the Present Article

1. YOKOYAMA, Shoichi and Takao OGINO (1984) : "Kango jiten jikitepu no dokyumento" (Document of Magnetic Tapes of Japanese Language Dictionary), Denshi Gijutsu Sogo Kenkyusho Iho (Bulletin of the Electrotechnical Laboratory), vol. 48, no 8, pp. 30-35.

2. Nihon Joho Shori Kaihatsu Kyokai (Japan Information Processing Development Center), Shizen Gengo no Konpyuta Kaiseki-go Jisho ni kansuru Chosa Kenkyu Hokokusho (Research Report on MachineReadable Dictionaries for Natural Language Processing. JIPDEC; 60-S002), $238 \mathrm{p}$. The English summary version of the above Report is available under the same title. "

3. ISHIWATA, T. et al. (1985) : Basic Specifications of the Machine-Readable Dictionary, ICOT Technical Report, TR-100, $34 \mathrm{p}$.

4. ANEZAKI, Naohiro (1984) : "Nihon Denshika Jisho Kenkyusho ni okeru denshika jisho no kenkyu haihatsu keikaku" (Research and Development Plan for Electronic Dictionaries in Japan Electronic Dictionary Research Institute Ltd.), Kikai Shiko (Machinery Promotion), no 217, pp. 34-39. 
5. Tsusansho Kikai Joho Sangyo Kyoku Denshi Seisaku-ka (Electronic Policy Division, Machinery and Information Industries Bureau, Ministry of International Trade and Industry) (1986) : "Shizen Gengo Shori-yo denshika jisho" (Electronic Dictionaries for Natural Language Processing), Kikai Shinko (ditto), n' 219.

6. Nihon Kagaku Gijutsu Joho Senta (Japan Information Center of Science and Technology : JICST), JICST Kagaku Gijutsu Yogo Sisorasu (JICST's Thesaurus of Scientific and Technical Terms).

7. JICST (1985) : JOIS Nyumon; Tanmatsuki no Sosa to Komando no Gaiyo (Introduction to JOIS : Outline of the Operation and Command of Terminals), $36 \mathrm{p}$.

8. Nihon Keizai Shinbun-sha (Japan Economic Newspaper Co.), Nihon Keizai Shinbun-sha no Kiji Joho Banku : NEEDS-IR Sisorasu (Newspaper Articles Bank of Japan Economic Newspaper Co. : NEEDS-IR Thesaurus).

9. Nihon Keizai Shinbun-sha (ditto) (1982) : Nihon Keizai Shinbun-sha no Kiji Banku : NEEDS-IR Kensaku no Tebiki (ditto : Guide to the Retrieval of NEEDS-IR), $87 \mathrm{p}$.

1.0. Nihon Toshokan Kyokai (Japan Library Association) (1983) : Nippon Jisshin Bunruihyo (Nippon Decimal Classification Table), $8^{\text {th }}$ ed., 685 p.

1. Nihon Joho Kagaku Kyokai (Information Science and Technology Association) (1984) : Kokusai Jisshin Bunruihyo; Chukan ban, Sakuin (Universal Decimal Classification; Japanese Simplified Edition, Relative Index).

12. NAGAO, M. et al. (1980) : "An Attempt to Computerize Dictionary Data Base", Proceedings of COLING '80.

13. UEDA, Yoshihiro : Shin Konsaisu Ei-Wa Jiten : Riyo Tebikisho (New Concise English-Japanese Dictionary : Users' Guide).

14. Inter-Press Co. (1983) : Kagaku Gijutsu 25 Mango Daijiten (Great Dictionary of 250000 Scientific and Technical Terms) ; Japanese-English 1, 888 p.; English-Japanese 1, 927 p.

15. Nihon Kagaku Gijutsu Joho Senta, Denshi Gijutsu Sogo Kenkyusho, Kyoto Daigaku (ditto, ditto, Kyoto University), Nichi-Ei Kagaku Gijutsu Bunken no Sokuho Shisutemu ni kansuru Kenkyu, Nichi-Ei Kagaku Gijutsu Yogo Jisho Deta Besu no Kaihatsu ni kansuru Hokokusho (Research Report on the Quick Reporting System of Japanese and English Scientific and Technological Literature ; Development of a Dictionary Database of Japanese and English Scientific and Technological Terms), 1985.3.

16. Denshi Gijutsu Sogo Kenkyusho, Kyoto Daigaku (ditto Kyoto University), Nichi-Ei Kagaku Gijutsu Bunken no Sokuho Shisutemu ni kansuru Kenkyu, Gengo Shori Shisutemu no Kaihatsu ni kansuru Hokokusho (Development of Language Processing System), 1985.3.

17. Kogyo Gijutshu In Somubu, Keikakuka (Joho Keisan Senta) ((Information-Computation Center) Planning Section, General Affairs Department, Industrial Technology Agency), Nichi-Ei Kagaku Gijutsu Bunken no Sokuho Shisutemu ni kansuru Kenkyu, Sogo shisutemu no Kaihatsu ni kansuru Hokokusho (Development of the Total System), 1985.3.

18. SAKAMOTO, Y., M. SATOH and T. ISHIKAWA (1984) : "Lexicon Features for Japanese Syntactic Analysis in Mu-Project-JE", Proceedings of COLING '84,

19. SAKAMOTO, Y., T. ISHIKAWA and M. SATOH (1986) : "Concept and Structure of Semantic Markers for Machine Translation in Mu-Project", Proceedings of COLING '86.

Further References

1. Tsusho Sangyo Sho Kikai Joho Sangyo Kyoku Ed., Databeisu Shinko Senta (Database Promotion Center) Comp., Detabeisu Hakusho (Whitepaper of the Database), 1986 ed., 403 p. The English summary version is available. Database Promotion Center, Japan. Database Services in Japan, 1986, 16 p.

2. Nihon Denshi Kogyo Shiko Kyokai (Japan Electronic Industry Development Association : JEIDA), Nihongo Shori Gijutsu ni kansuru Chosa Kenkyu (Research on the Processing Technology of the Japanese Language : 58-C-54), 1983, 302 p.

3. Joho Shori Shinko Jigyo Kyokai (Information Technology Promotion Agency, Japan : IPA), Sofuto Ueya Bunsho no tame no Nihongo Shori no Kenkyu (5) - Keisanki yo Rekishikon no tame ni (Research on the Japanese Language Processing for the Software (5) - For the Lexicon Utilized for the Computer. 58 Tech.-029), 1983, 380 p.

4. Ibid., Keisanki Rekishikon no tameni (2) (ditto (2) 60 Tech.-060), 1986, 380 p.

* This contribution is an abridged version of a comprehensive article jointly written by Masanobu Fujikawa and Tetsuya Ishikawa (Associate Professor of ULIS), which is available as document TermNet, 1987, from Infoterm. 